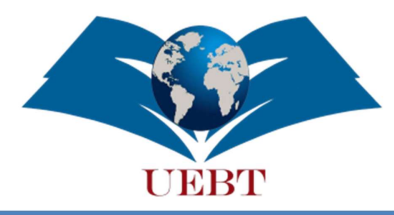

Uluslararası Eğitim Bilim ve Teknoloji Dergisi

\title{
OKUL ÖNCESİ DÖNEM ÇOCUKLARDA EGO SAĞLAMLIĞI VE RUHSAL UYUM ARASINDAKİ İLIŞKINIIN İNCELENMESİ*
}

\author{
Ayşe ÇETINKKAYA**, Arzu ÖZYÜREK***
}

Makale Geliş Tarihi: 25.10. 2021

Makale Kabul Tarihi:13.12.2021

\section{Özet}

Bu çalışmada, okul öncesi dönem çocuklarının ego sağlamlıkları ile ruhsal uyumları arasındaki ilişkinin incelenmesi amaçlanmıştır. Çalışmada ayrıca kişisel bazı değişkenlere göre çocukların ego sağlamlığı ve ruhsal uyumları incelenmiştir. Çalışma grubunu 5-6 yaşındaki 311 çocuk oluşturmuştur. Veriler çocukların annelerinden elde edilmiş̧ir. Veri toplamada Çocuk Ego Sağlamlığı Ölçeği ve Hacettepe Ruhsal Uyum Ölçeği kullanılmıştır. Verilerin normal dağılım göstermemesi nedeniyle parametrik olmayan testlerden Spearman Brown Korelasyon analizi, Mann Whitney U Testi, Kruskal Wallis-H Testi kullanılmıştır. Araştırma sonucunda çocukların ego sağlamlık düzeylerinin cinsiyet, kardeş sayısı, anne-baba yaşı ve öğrenim durumuna göre farklılık göstermediği belirlenmiştir. Çocukların ruhsal uyumlarının cinsiyet, kardeş sayısı, doğum sırası ve anne-baba yaşına göre farklılık göstermediği; annesi lise mezunu olan çocukların ruhsal uyumları annesi lisans mezunu olanlardan ve babası ortaokul mezunu olan çocukların ruhsal uyumları babası lise, ön lisans ve lisans mezunu olanlardan daha yüksek bulunmuştur. Çocukların ego sağlamlık düzeyleri ile ruhsal uyumları arasında anlamlı bir ilişki olmadığı belirlenmiştir.

Anahtar Kelimeler: Ruhsal Uyum, ego sağlamlığı, okul öncesi dönem.

\section{INVESTIGATION OF THE RELATIONSHIP BETWEEN EGO STRENGTH AND SPIRITUAL HARMONY IN PRE-SCHOOL CHILDREN}

\footnotetext{
Abstract

In this study, it was aimed to examine the relationship between ego resilience and the psychological adjustment of preschool children. In the study, children's ego resilience and psychological adjustment were also examined

**Bu çalışma, Ayşe Çetinkaya tarafından Prof. Dr. Arzu Özyürek danışmanlığında yürütülen yüksek lisans tezinin bir bölümünü kapsamaktadır.

** Öğretim Görevlisi, İstanbul Aydın Üniversitesi, aysecetinkaya@aydin.edu.tr, ORCID: 0000-0002-6873-6239

*** Profesör, Karabük Üniversitesi, a.ozyurek@karabuk.edu.tr, ORCID: 0000-0002-3083-7202
} 
according to some personal variables. The study group consisted of 311 children aged 5-6 years. The data were obtained from the mothers of the children. Child Ego Resilience Scale and Hacettepe Mental Adjustment Scale were used to collect data. Spearman Brown Correlation analysis, Mann Whitney U Test, Kruskal Wallis-H Test, which are non-parametric tests, were used because the data did not show normal distribution. As a result of the research, it was determined that the ego resilience levels of the children did not differ according to gender, number of siblings, parental age and educational status. The psychological adjustment of children did not differ according to gender, number of siblings, birth order and parental age; The psychological adjustment of the children whose mothers were high school graduates and those whose fathers were secondary school graduates were found to be higher than those whose fathers were high school graduates, associate degree and undergraduate students. It was determined that there was no significant relationship between the children's ego resilience levels and their psychological adjustment.

Keywords: Spiritual harmony, ego strength, preschool period.

\section{GIRIŞ}

Bireylerin topluma uyumunda sağlıklı bir kişilik geliştirmesi önemlidir. Sağlıklı bir kişilik geliştiren bireyler yeni durumlara uyum sağlayabilir, karşılaştığı her türlü olumsuzlukla daha kolay başa çıkabilir ve başarılı olma gibi olumlu durumların sürekliliği için motive olabilir. Tüm gelişim alanları birbiriyle yakından ilişkili olduğu gibi kişilik gelişimi de bireyin duygu, düşünce veya davranışlarıyla ilişkili, çok yönlü bir süreçtir.

Freud, kişiliğin duygusal yönden incelenmesi gereken bir olgu olduğunu savunmuştur. Bu duygusal tutum ve davranışlarda en belirgin kavram bilinçaltıdır. Freud kişiliği üç başlığa ayırmıştır. Bunlar id, ego ve süperegodur. İd, bireyin ilkel benliği, ego ilkel benliğin sosyal yaşantıya uygun olmayan durumları bastırarak kişinin sosyal düzene uymasını sağlar, süper ego ise idin karşıtıdır (Eren, 2001). Ego, algı ve bilişin gelişmesiyle gerçeklik üzerine değerlendirme yapmaktadır. Alt benlikten gelen dürtüyü değerlendiren ego, uygun olmayan koşullara karşı tepki vermekte ve içinde bulunulan duruma karşı ihtiyacın gerçeklik ilkesi üzerine giderilmesine temel hazırlamaktadır. Bu süreçte ego, kişinin bilinçli olarak düşünmesini, yargılamasını ve akıl yürütebilmesi gibi görevleri üstlenmektedir. Alt benlikten gelen uyaranı değerlendiren ego, üst benlik sebebiyle toplumun gerektirdiği ahlak ve vicdan kurallarına göre üst benliğin baskılarını dengeleyen bir yapıya sahiptir (Oktuğ, 2007). Ego gelişiminin genetik etkenler de dikkate alındığında döllenmeyle birlikte oluşmaya başladığı söylenebilir. Doğumdan sonra fiziksel gelişim, ardından ruhsal ve sosyal gelişim egonun oluşumunu etkilemektedir. Bebeklerin kendine özgü kişilikleri vardır ve etrafındakiler için bazı davranışlar sergilerler. İki yaşına kadar geçen evrede bireysel olarak oynayan ve akranlarıyla iletişim kuramayan çocuklar, zamanla ürkekliklerini atarak öteki kişilerle iletişime geçmektedirler (Avcı, 2007). Çocuklarda ego algısı nitelik, kabiliyet, davranış ve değerlerinin kendine has inanışla tanımlanması sonucunda yapılanmaya başlamaktadır (Berk, 2013). Egonun yapısı, çevreyle ve bilhassa ebeveyn, arkadaş vb. insanlarla etkileşimler neticesinde biçimlenmektedir (Yanbastı, 1990). Sağlıklı bir kişilik gelişimi ve olumlu ilişkiler için ise ego sağlamlığı kavramından söz edilmektedir.

Ego sağlamlığı, kişinin güçlü koşulları başarıyla atlatabilme ve böyle durumlara uyum gösterebilme yeteneği olarak tanımlanmaktadır. Ego sağlamlığı bir yetenek olmakla beraber gelişimin uygun bir şekilde sürdürülerek olumsuz olgularla mücadele edilmesi gibi özelliğe 
sahiptir (Masten ve Coatsworth, 1998). Temel olarak risk faktörü olmasına karşın gelişimin pozitif olarak devam etmesi, ego sağlamlığı olarak tanımlanmaktadır. Ego sağlamlığı, ruhsal açıdan sağlıklı olma ile ilişkilendirilmektedir ve ruhsal sağlamlık olarak kaynaklarda ele alınmaktadır. Ruhsal sağlamlık kavramı Latince "resiliere" sözcüğünden türemiştir ve zorluklara karşı olumlu uyum sağlama becerisidir (Masten ve Gewirtz, 2006). Literatürde bu terim yılmazlık (Çelik, 2013) ego sağlamlığı (Önder ve Gülay Ogelman, 2011) ya da psikolojik sağlamlık (Gizir, 2007) gibi farklı isimlerle kavramsallaşmaktadır. Murphy (1987) ruhsal sağlamlık kavramını stres dolu hayat olayları ile hangi yolları kullanarak mücadele edildiğini ve tekrardan toparlanmanın ne şekilde temin edildiğini merkeze alan bir kavram şeklinde açıklamaktadır. Ramirez'e (2007) göre ruhsal sağlamlık hastalıkların, negatif şartların veya değişmelerin ardından kısa bir süre içinde toparlanma, eski duruma dönme yeteneğidir. Masten ve Coatsworth (1998) ruhsal sağlamlığı, çetin güçlükler sonunda uyum ve gelişim gösterme yeteneğidir. Zaman içinde değişebilen bu sistem, güçlüklerle karşılaşma ve güçlüklerle başarılı bir şekilde mücadele ederek olumlu uyum gösterme becerileriyle açıklanmakla birlikte ruhsal sağlamlığın canlı bir yapısının bulunduğu anlaşılmaktadır. $\mathrm{Bu}$ tanımlamalara göre ego sağlamlığı iyi korunup olumsuz durumlarda güçlü bir şekilde ortaya çıkarsa gelecek olumsuz durumlarla baş etme seviyesi güçlenir. Zorlu yaşam şartlarıyla karşılaşmadan yaşamda başarılı olanlar için ruhsal sağlamlıktan söz etmek doğru değildir. Bu insanlar sadece başarılı veya yeterli olarak nitelendirilebilir. Kısacası, ruhsal sağlamlıktan söz edebilmek üzere bireyin risk grubunda bulunmasına veya örseleyici olaylara maruz kalmasına karşılık sağlıklı uyum gösterebilmesi ve yaşamın farklı sahalarında başarıyı yakalayabilmesi gerekmektedir (Luthar ve Cicchetti, 2000).

Okul öncesi yıllar, ego gelişiminde önemli bir zaman dilimidir. Bu nedenle, okul öncesinden itibaren çocuklarda ego ve ego sağlamlığının desteklenmesi ve gelişimi üzerinde durulması gerekmektedir. Çocukların erken dönemde ego sağlamlığının gelişmiş olması sağlıklı gelişim için olması gereken yetiler arasındadır (Gülay Ogelman ve Özyürek, 2020). Anne-baba ve çocuk ilişkileri çocukların ego sağlamlıklarını artırır, stresten korur ve karşılaşılan güçlüklerle mücadele edebilmesini sağlar. Bu açıdan, olumlu aile ortamı ve çocuğun desteklenmesi ego sağlamlığını artıran bir etmendir (Öngören ve Y1lmaz, 2018). Ego sağlamlığının yüksek olması çocukların beklenmedik olgularla karşılaştığında bunlara rahat tepkiler vermesini, stresle başa çıkma düzeyini belirleyebilmesini, zorlu koşullarda direnç sağlamasını ve böyle durumlarda etkili problem çözme stratejileri geliştirmesini sağlayacaktır (Block ve Block, 1980). Çocuk ve ergenlerin ego sağlamlık düzeylerinin yüksek olması için ilk olarak kişiye karşı risk unsurlarının bulunması, bunlara karşın kişinin uyum ve gelişme kapasitesinin artırılması gerekmektedir. Ego sağlamlığı, risk etkenleri karşısında uyum geliştirmeye yatkın olmakla alakalı bir terimdir. Ego sağlamlık seviyesi fazla olan bireyler, değişmekte olan durumlara kolayca uyum sağlayabilmekte, gereken hallerde davranışlarını düzenleyebilmekte ve sorun çözme stratejisini esnek biçimde kullanabilmektedirler (Masten ve Coatsworth, 1998). Ego sağlamlık düzeyi yüksek seviyede olan çocuklar da yoksulluk, anne-babanın ilgisiz tutumu, hastalık gibi önemli risk etkenlerine karşı pozitif gelişimlerini sürdürebilmektedir (Gizir, 2007). Ego sağlamlığı düşük olan çocuklar, ise sorunlara karş1 daha az esneklik gösterebilmekte, değişimlerden rahatsızlık duymakta, stres ile yaşadıkları travmatik olaylara karşı mücadele etme konusunda zorlanmaktadırlar. Ruhsal sağlamlık, 
toplumsal yetkinlik (Block ve Block, 2006), içselleştirme ve dişsallaştırma sorunları (Hofer, Eisenberg ve Reiser, 2010), zihinsel ve dikkate yönelik fonksiyonlarla ilişkilidir (Martel vd., 2007). Kimi kişisel (Eisenberg, Spinrad ve Morris, 2002), ailevi (Stams, Juffer, Van IJzendoorn ve Hocksbergen, 2001) ve çevresel (Masten ve Coatsworth, 1998) etkenlerin, ego sağlamlığıyla alakalı olduğu bilinmektedir. Ego sağlamlığının gelişimini ruhsal uyum da büyük ölçüde etkilemektedir.

Bireylerin ihtiyaçlarını karşılamaya, dürtülerini doyurmaya, karşı karşıya kaldığı problemleri çözümlemeye gayret etmesi ruhsal uyum çabalarından ibarettir. Kişiler, kendisinde ve çevresindeki değişikliklerle bunu başarmaya çalışmaktadırlar. Dürtüleriyle ve istekleriyle çevresel şartları akılcı bir biçimde bir araya getirmek, başarılı bir uyum için gereklidir. Karşılıklı etkileşim içerisindeki kişi, daha önce öğrendikleri ile yeni uyum örüntüleri geliştirmektedir (Enç vd., 1987). Ruhsal uyum, yalnızca toplumsal çevrenin talepleriyle değişikliklerine uyan tepki, davranış ve tavır göstermektedir. Bireyler doğduklarından itibaren hayat boyu bir değişim ve gelişim içindedir. Bireylerin zihinsel, ruhsal, duygusal, toplumsal ve biyolojik bir hayatı bulunmaktadır. Bunların uyumlu bir biçimde olması kişinin bütün hayatını teşkil etmektedir ve bu dengeler bozulduğu zaman uyumsuz davranışlar görülmeye başlamaktadır (Yanbast1,1990). Arkadaşlarıyla iyi ilişkiler kuran, oyunlara kimi zaman lider olarak kimi zaman da üye olarak katılabilen, okulunda yeteri seviyede başarı gösteren, sınav kaygısı ile baş edebilen, karşılaştığı sorunlara karşı kendi kendine çözüm bulabilen, insanlarla iletişim kurarken zorlanmayan, toplumsal kuralları ve disiplinleri kabul edebilen, duygularını ifade ederken zorlanmayan, olası hallerde kendisini savunabilen, yenildiği zaman oyunlarda yenilgiyi kabul edebilen, yardımlaşmayı seven çocuk, ruhsal yönden uyumlu olarak tanımlanmıştır (Aydoğmuş, 1990). Kişi içinde bulunduğu arkadaş ortamı dışında farklı gruplara girip sağlıklı iletişim kurabiliyorsa, toplum tarafından beklenen tutumların içinde bulunması gerekiyorsa ve bunları yaparken yeterli hazzı alabiliyorsa uyumlu olduğu söylenebilir. Bu açıklamaya göre uyum, kişinin kendisinde bulunan özelliklerin kendi benliği ve çevresi arasında dengeyi sağlayabilmesi ve bunu devam ettirebilmesidir (Yavuzer, 1982).

Kişilerin uyumu, kendisi ve yaşadığı sosyal çevresiyle uyumlu olduğu takdirde sağlıklıdır. Uyum, davranışsal ve sosyal etkileşimle birlikte hayat boyu devam eder (Yörükoğlu 1996). Uyum gerektiren hareketlerin, olgunlaşma, öğrenilme ve sosyal çevreye karşı uyumlu olmak gibi üç boyutu bulunmaktadır. Olgunlaşma, fizyolojik değişimin sonucu olarak ortaya çıkar ve davranış farklılığını açıklar. Kişilerin yaşanılan hayattan doyum alması, uyuma giden yolları öğrenmiş olmasına bağlıdır. Sosyal uyum, toplum normlarına uyum ve mesleki yeterliliği barındırma özelliklerini açıklamaktadır. Uyumsuz olmak bireyi mutsuz ederken toplum tarafından bakıldığında ise verimliliğin azalmasına neden olur ve boşa harcanan insan gücü anlamına gelmektedir, bu da uyumun önemini açıklamaktadır (Kurç, 1990). Bu durum yaşanan kültürel faktörlerin öneminin büyük olduğunu ortaya koymaktadır. Çocukluk dönemindeki uyumsuzlukların en önemli etkenlerinden birisi, çocuğun ilk tanıştığ1 sosyal grup olan ailesidir. Çocuğun erkek ya da kız oluşu, parçalanmış aile, sosyoekonomik durum, aile içi ilişkiler, anne ya da babanın olumsuz rol model oluşu, aile üyelerindeki psikolojik sorunlar uyumsuzluğa ve bunun sonucunda davranış bozukluğuna sebep olmaktadır 
(Alisinanoğlu ve Ulutaş, 2000). Çocuğun herhangi bir gelişimsel bozukluğa neden olan kromozom bozukluğu, kalıtsal hastalık, gen farklılığı ve sonradan fiziksel engellilik durumu da ruhsal uyumu etkileyen faktörler arasındadır (Gençtan, 1993).

Bireyin sağlığı söz konusu olduğunda, ego sağlamlığı ve ruhsal uyumun yakından ilişkili olduğu görülmektedir. Ego sağlamlığı ve ruhsal uyum, bireyin kişisel ve çevresel uyumunu kolaylaştıran faktörlerdendir. Ego sağlamlığının oluşmaya başladığı erken çocukluk döneminde, çocukların içinde bulunduğu çevresel şartlar ve kültür etkili olmaktadır (Wolkow ve Ferguson, 2001). Ayrıca ihmal, istismar, şiddet ve kötü muamele gibi olumsuz yaşam tecrübelerine maruz kalan çocuklar ileriki yaşamlarında kötü yaşam deneyimlerini yansıtma eğilimindedirler (Brooks, 2006; Masten, 2011). Kötü yaşam deneyimleri sonucunda çocukların ortaya çıkardığı olumsuz tepkiler, çevresine de kolay uyum sağlayamayacağı anlamına gelmektedir. Çocuk ve ergenlerin ego sağlamlık seviyesi yüksek ise sosyal (Block ve Block, 2006) problemlere karşı çözüm üretebilme yetileri, iyimser oluşları, hedef ve geleceği düşünme (Stipek, Recchia ve McClintic, 1992) durumları oldukça iyi düzeydedir. Prince-Embury (2015) yapmış olduğu çalışmada akademik olarak iyi olmanın, okula gidişin sürekliliği ve mezuniyet durumunun ego sağlamlığıyla ilişkili kavramlar olduğunu belirtmiştir. Kwok, Hughes ve Luo'nun (2007) çalışmalarında birinci sınıf ve ikinci sınıfta gözlemlenen çocukların ego sağlamlığının, akademik başarı için etkili bir faktör olduğunu ortaya koymuşlardır. Bununla birlikte Bayındır, Önder ve Balaban-Dağal'ın (2016) yapmış olduğu çalışmada Türkiye'deki okul öncesi dönem çocuklarının ego sağlamlıklarının okula hazır bulunuşlukla doğrudan ilişkili olduğu ifade edilmiştir. Yapılan bu çalışmaların, genellikle okul çağı ve ergenlik dönemine odaklandığı görülmektedir. Erken yıllardan itibaren gelişmeye başlayan ego sağlamlığı ve etkileyen faktörlerin, okul öncesi dönemde incelenerek olası risklerin ortaya konması gereğinden yola çıkılarak bu çalışmada, okul öncesi dönem çocuklarının ego sağlamlıkları ile ruhsal uyumları arasındaki ilişkinin incelenmesi amaçlanmıştır. Aşağıdaki alt problemlere cevap aranmıştır:

•Okul öncesi dönem çocukların ego sağlamlığı cinsiyet, kardeş sayısı, doğum sırası, anne-baba yaşı ve öğrenim düzeyine göre farklılaşmakta mıdır?

•Okul öncesi dönem çocukların ruhsal uyumları cinsiyet, kardeş sayısı, doğum sırası, anne-baba yaşı ve öğrenim düzeyine göre farklılaşmakta mıdır?

-Okul öncesi dönem çocukların ego sağlamlığı ve ruhsal uyumları arasında bir ilişki var midır?

\section{YÖNTEM}

Nicel olarak tasarlanan bu çalışma tarama modelinde yürütülmüştür. Nicel çalışmalar, nesnel ve genellenir bilgilere erişmek amaciyla pozitivist paradigma etrafında yapılan çalışmalar olarak tanımlanır (Kuş, 2009). Tarama modelli araştırmalarda birçok eleman bulanan evrenle ilgili genel bir kanıya varmak için evrenin tamamı veya onun içinden alınacak bir grup örneklem üzerinde uygulanan tarama düzenlemesidir. Bu araştırmada, okul öncesi dönem çocuklarının ego sağlamlıkları ile ruhsal uyumları arasındaki ilişkinin incelenmesi amacıyla ilişkisel tarama modeli temel alınmıştır. İki veya daha fazla sayıdaki 
değişkenin birlikte olan değişkenliği ya da değişimin varlığı, derecesini ortaya çıkarmayı hedefleyen araştırma modeline ilişkisel tarama modelli çalışmalar denilmektedir (Karasar, 2014).

\subsection{Veri Toplama Araçları}

Verilerin toplanmasında, Kişisel Bilgi Formu, Çocuk Ego Sağlamlığı Ölçeği ve Hacettepe Ruhsal Uyum Ölçeği kullanılmıştır.

Kişisel Bilgi Formu, çocuğunun cinsiyeti, kardeş sayısı, doğum sırası, anne ve baba yaşı, anne ve baba öğrenim durumu ve aile yapısını belirlemeye dönük soruları içermektedir.

Çocuk Ego Să̆lamlı̆̆ı Ölçeği, 1996 yılında, Eisenberg ve arkadaşları tarafindan Block'un QSort yönteminden uyarlanarak geliştirilmiştir. Ölçek çocukların gözlemlenmesine dayalı olarak anne-baba veya öğretmenler tarafından doldurulmaktadır. Ölçek, 12 maddeli ve 9'lu likert türündeki tek boyuttan oluşmaktadır. Değerlendirme "hiç tanımlamıyor" 1 puan, "çok tanımlamıyor" 2 puan, "oldukça tanımlamıyor" 3 puan, "biraz tanımlamıyor" 4 puan, "ne tanımlıyor ne de tanımlamıyor" 5 puan, "biraz tanımlıyor" 6 puan, "oldukça tanımlıyor" 7 puan, “çok tanımlıyor" 8 puan ve "tamamen tanımlıyor" 9 puan olarak yapılmaktadır. Ölçekten alınabilecek en düşük puan 12, en yüksek puan ise 108'dir. Çocukların ölçekten aldıkları puana göre ego sağlamlık düzeyi yükselmekte, puan azaldıkça ego sağlamlık düzeyi düşmektedir.

Hacettepe Ruhsal Uyum Envanteri, Hacettepe Üniversitesi Tıp Fakültesi Çocuk ve Ergen Ruh Sağlığı ve Hastalıkları Anabilim Dalı tarafından, ruhsal uyumu değerlendirmek için uygulanan farklı ölçeklerden Türkiye'de uygulanabilecek olan sorular seçilmiş ve geliştirilmiş, geçerlik ve güvenirlik çalışması yapılmış olan bir ölçektir. 1985 yılında Gökler ve Öktem tarafindan geliştirilen bu ölçek, tüm çocuklarda görülebilecek ruhsal belirtileri içeren 32 maddeden oluşmaktadır. Her madde için "Yok", "Biraz", "Çok" seçenekleri bulunmakta; puanlama, bu seçeneklerin karşılıkları olan 0, 1, 2 puanlar toplanarak yapılmaktadır. İçsel ve dışsal davranışları ölçen 24 maddeden on üç ve yukarısı puan alınmış olması davranış sorununun olduğunu belirtmektedir. Tek sayılı maddeler nevrotik sorunları, çift sayılı maddeler davranış problemlerini göstermektedir. Ölçekte ilk 24 maddeyle ilgili maddeler toplanmaktadır. Toplam 13 ve yukarısında puan alınması durumunda "ruhsal bir sorun varlığından söz edilebilir" denilmektedir. Ölçeğin üç alt boyutu bulunmaktadır. "İçselleştirme sorunları" alt boyutunda çekingenlik, her şeye ağlama, arkadaşsız olma ve yalnız oynama, durgun ve içine kapanık olma gibi sorun alanlarını içeren 12 madde yer alırken "dışsallaştırma sorunları" alt boyutu ise hareketlilik, sinirlilik, söz dinlememe, yalan söyleme gibi sorun alanlarını değerlendiren 12 maddeden oluşmaktadır. Ölçekte uyum saptamak amacıyla 24 sorunun yanı sıra, kekemelik, tik, tırnak yeme, parmak emme, kaka kaçırma, yatağa işeme ya da okul başarısızlığı gibi 7 ruhsal belirti bulunmakta ve en kaygı verici sorunla en olumlu özelliğinin belirtilmesi istenmektedir. Ölçeğin Cronbach alfa iç tutarlık katsayısı 0,86’dır (Gökler ve Öktem, 1985). Bu çalışmada iç tutarlılık katsayısı ölçek 
tümü için 0,80 , içselleştirme sorunları için 0,71 ve dışsallaştırma sorunları için de 0,68 olarak hesaplanmıştır.

\section{2.Çalışma Grubu}

Çalışma grubunu 157 kız ve 152 erkek olmak üzere 311 okul öncesi 5-6 yaşında çocuk oluşturmuştur. Çalışma grubuna ilişkin bazı demografik bilgiler Tablo 1'de sunulmuştur.

Tablo 1. Çalışma grubuna ait demografik bilgiler

\begin{tabular}{lcclcc}
\hline Doğum Sırası & $\mathrm{n}$ & $\%$ & Kardeş Sayısı & $\mathrm{n}$ & $\%$ \\
\hline İlk çocuk & 212 & 68,17 & Tek çocuk & 128 & 41,16 \\
2.çocuk & 65 & 20,90 & 2 veya 3 kardeş & 183 & 58,84 \\
3.ve sonraki & 34 & 10,93 & & & \\
\hline Toplam & 311 & 100 & Toplam & 311 & 100 \\
\hline Anne Yaşı & & \multicolumn{5}{c}{ Baba Yaşı } & 41 & 13,18 \\
\hline 25 yaş ve daha küçük & 16 & 5,14 & $26-30$ yaş & 126 & 40,51 \\
26-30 yaş & 111 & 35,69 & $31-35$ yaş & 100 & 32,15 \\
31-35 yaş & 117 & 37,62 & 36-40 yaş & 28 & 9,00 \\
36-40 yaş & 48 & 15,43 & $41-45$ yaş & 16 & 5,14 \\
41 yaş ve üzeri & 19 & 6,11 & 46 yaş ve üzeri & 311 & 100 \\
\hline Toplam & 311 & 100 & Toplam & 17 & 5,47 \\
\hline Anne Öğrenim & & \multicolumn{5}{c}{ Baba Öğrenim } & 22 & 7,07 \\
\hline İlkokul & 17 & 5,47 & İlkokul & 75 & 24,12 \\
Ortaokul & 16 & 5,14 & Ortaokul & 29 & 9,32 \\
Lise & 63 & 20,26 & Lise & 125 & 40,19 \\
Ön Lisans & 49 & 15,76 & Ön Lisans & 43 & 13,83 \\
Lisans & 137 & 44,05 & Lisans & 311 & 100 \\
Lisans üstü & 29 & 9,32 & Lisans üstü & \\
\hline Toplam & 311 & 100 & Toplam & &
\end{tabular}

Tablo 1'e göre kardeşi olmayan çocuk \%41 iken, 2 veya 3 kardeşi olan çocuklar \%59'dur. Çocukların doğum sıralarının ilk olması \%68, ikinci olması \%21, üçüncü ya da daha sonra olması \%11'dir. Çocukların annelerinin \%36'sı 26-30 yaşında, \%38'i 31-35 yaşında, \%15'i 36-40 yaşında; babalarının \%41'i 31-35 yaşında, \%32'si 36-40 yaşındadır. Annelerin $\% 20$ 'si lise, \%15'i önlisans, \%44'ü lisans ve \%9'u lisansüstü bölüm mezunu; babaların ise \%24'ü lise, \%40'1 lisans ve \%13,83'ü lisansüstü mezunudur.

\subsection{Verilerin Analizi}

Çalışma öncesi Karabük Üniversitesi Sosyal ve Beşerî Bilimler Araştırmaları Etik Kurulu'ndan etik uygunluk belgesi alınmıştır. Gerekli izin alındıktan sonra 2020 Eylül ayı itibariyle, onay formu ve ölçek maddeleri çevrimiçi ortamdan 5-6 yaş çocuğu bulunan annelerle paylaşılmıştır. Ölçek formu anneler tarafından doldurulmuştur. Daha sonra sıra ile ölçme araçlarında bulunan talimatlar uygulanmıştır. Google formlar üzerinde elde edilen veriler sayısal kodlara dönüştürülerek istatistik analiz programına aktarılmıştır. 
Verilerin analizinde hangi istatistik yöntemlerinin kullanılmasının uygun olacağını belirlemek amacıyla normallik varsayımı sınanmıştır. Bu amaçla Kolmogorov-Smirnov Testi yapılmış, basıklık ve çarpıklık değerleri, varyasyon katsayıları, histogram ve Q-Q plot grafikleri incelenmiştir. Kolmogorov-Smirnov Testi sonucu anlamlılık değeri 0,05'ten küçük, basıklık ve çarpıklık katsayıları \pm 2 aralığında, histogram ve Q-Q Plot grafiklerinin normal dağılıma uygun olmadığı görülmüştür. Aynı şekilde cinsiyet, kardeş sayısı, yaş, doğum sırası, anne-baba yaşı ve öğrenim düzeyine göre de normallik varsayımları incelenerek verilerin normal dağılmadığı görülmüştür. $\mathrm{Bu}$ nedenle çalışmada ikili değişkenlerin karşılaştırmalarında Mann Whitney $U$ (MWU) testinden, ikiden çok değişken karşılaştırmalarında ise Kruskal Wallis-H (KWH) testinden yararlanılmıştır. İkiden çok değişken karşılaştırmalarında elde edilen ortalamalarda gruplar arası farklılıklar gözlenmesi durumunda, farkın kaynağı MWU testi ile incelenmiştir. İki ölçek puanı arasındaki ilişkinin belirlenmesinde Spearman Brown Korelasyon katsayısına bakılmıştır.

\section{BULGULAR}

Cinsiyete göre Çocuk Ego Sağlamlığı Ölçeği ve Hacettepe Ruhsal Uyum Envanteri puanlarına ilişkin MWU Testi sonuçları Tablo 2'de, kardeş sayısına göre MWU testi sonuçları Tablo 3 'te ve doğum sırasına göre KWH Testi sonuçları Tablo 4'te verilmiştir.

Tablo 2. Cinsiyete göre Çocuk Ego Sağlamlığı Ölçeği Ve Hacettepe Ruhsal Uyum Envanteri puanları MWU testi sonuçları

\begin{tabular}{llccccc}
\hline & Cinsiyet & $\mathrm{N}$ & $\overline{\mathrm{x}}$ & $\mathrm{S}$ & $\mathrm{z}$ & $\mathrm{p}$ \\
\hline Çocuk Ego Sağlamlığ̀ Ölçeği & Kız & 157 & 64,74 & 12,26 & $-0,552$ & 0,581 \\
& Erkek & 154 & 65,29 & 12,33 & & \\
\hline Hacettepe Ruhsal Uyum & Kiz & 157 & 9,50 & 5,11 & $-0,445$ & 0,656 \\
Envanteri & Erkek & 154 & 9,83 & 5,60 & & \\
\hline
\end{tabular}

Tablo 2'ye göre çocukların cinsiyeti ile Çocuk Ego Sağlamlığı Ölçeği ve Hacettepe Ruhsal Uyum Envanteri ortalama puanları arasındaki fark anlamlı değildir $(p>0,05) . \mathrm{Bu}$ bulguya göre okul öncesi çocukların erkek ya da kız olmaları, ego sağlamlık durumlarında ve ruhsal uyumlarında farklılık oluşturmamaktadır.

Tablo 3. Kardeş sayısına göre Çocuk Ego Sağlamlığı Ölçeği Ve Hacettepe Ruhsal Uyum Envanteri puanları MWU testi sonuçları

\begin{tabular}{|c|c|c|c|c|c|c|}
\hline & Kardeş Sayısı & $\mathrm{n}$ & $\overline{\mathrm{X}}$ & $\mathrm{S}$ & Z & $\mathrm{p}$ \\
\hline Çocuk Ego Sağlamlığı & Tek çocuk & 128 & 66,06 & 11,79 & $-1,319$ & 0,187 \\
\hline Ölçeği & 2 veya 3 kardeş & 183 & 64,28 & 12,58 & & \\
\hline Hacettepe Ruhsal Uyum & Tek çocuk & 128 & 9,91 & 5,82 & $-0,309$ & 0,757 \\
\hline Envanteri & 2 veya 3 kardeş & 183 & 9,50 & 5,01 & & \\
\hline
\end{tabular}

Tablo 3'e göre kardeş sayısı ile Çocuk Ego Sağlamlığı Ölçeği ve Hacettepe Ruhsal Uyum Envanteri ortalama puanları arasındaki fark anlamlı değildir ( $p>0,05)$. Bu bulguya göre 
okul öncesi çocukların tek ya da daha fazla kardeş olmaları ego sağlamlık durumları ve ruhsal uyumlarında farklılık oluşturmamaktadır.

Tablo 4. Doğum sırasına göre Çocuk Ego Sağlamlığı Ölçeği Ve Hacettepe Ruhsal Uyum Envanteri puanları KWH testi sonuçları

\begin{tabular}{llccccc}
\hline & Doğum Sırası & $\mathrm{n}$ & $\overline{\mathrm{x}}$ & $\mathrm{S}$ & $\mathrm{H}$ & $\mathrm{p}$ \\
\hline Çocuk Ego Sağlamlığı & İlk çocuk & 212 & 65,20 & 12,55 & 2,680 & 0,262 \\
Ölçeği & 2.çocuk & 65 & 63,14 & 11,95 & & \\
& 3.ve sonraki & 34 & 67,32 & 10,90 & & \\
\hline Hacettepe Ruhsal Uyum & İlk çocuk & 212 & 9,46 & 5,39 & 1,304 & 0,521 \\
Envanteri & 2.çocuk & 65 & 9,73 & 4,64 & & \\
& 3.ve sonraki & 34 & 10,87 & 6,37 & & \\
\hline
\end{tabular}

Tablo 4'e göre çocukların doğum sırası ile Çocuk Ego Sağlamlığı Ölçeği ve Hacettepe Ruhsal Uyum Envanteri ortalama puanları arasındaki fark anlamlı değildir $(\mathrm{p}>0,05)$. Bu bulguya göre okul öncesi çocukların ilk, ikinci ya da 3. ve sonraki çocuk olmaları değişkeni ego sağlamlık durumları ve ruhsal uyumları arasında farklılık oluşturmamaktadır.

Tablo 5-8 arasında Çocuk Ego Sağlamlığı Ölçeği ve Hacettepe Ruhsal Uyum Envanteri puanları arasında anne-baba yaşı ve öğrenim durumuna göre farklılık olup olmadığına ilişkin KWH test sonuçları verilmiştir.

Tablo 5. Anne yaşına göre Çocuk Ego Sağlamlığı Ölçeği ve Hacettepe Ruhsal Uyum Envanteri puanları KWH testi sonuçları

\begin{tabular}{llccccc}
\hline & Anne Yaşı & $\mathrm{n}$ & $\overline{\mathrm{x}}$ & $\mathrm{S}$ & $\mathrm{H}$ & $\mathrm{p}$ \\
\hline Çocuk Ego & 25 ve altı yaş & 16 & 66,00 & 15,35 & 1,528 & 0,822 \\
Sağlamlığı Ölçeği & 26-30 yaş & 111 & 65,33 & 13,73 & & \\
& 31-35 yaş & 117 & 64,39 & 10,84 & & \\
& 36-40 yaş & 48 & 64,75 & 12,40 & & \\
& 41 yaş ve üzeri & 19 & 66,84 & 8,93 & & \\
\hline Hacettepe Ruhsal & 25 ve altı yaş & 16 & 11,06 & 8,38 & 1,489 & 0,829 \\
Uyum Envanteri & 26-30 yaş & 111 & 9,61 & 5,75 & & \\
& 31-35 yaş & 117 & 9,33 & 4,49 & & \\
& 36-40 yaş & 48 & 9,45 & 4,75 & & \\
& 41 yaş ve üzeri & 19 & 11,42 & 6,24 & & \\
\hline
\end{tabular}

Tablo 5'e göre çocukların anne yaşı ile Çocuk Ego Sağlamlığı Ölçeği ve Hacettepe Ruhsal Uyum Envanteri ortalama puanları arasındaki fark anlamlı değildir $(p>0,05)$. Bu bulguya göre anne yaşı okul öncesi çocuklarının ego sağlamlık durumları ve ruhsal uyumlarında anlamlı farklılık oluşturmamaktadır. 
Tablo 6. Baba yaşına göre Çocuk Ego Sağlamlığı Ölçeği ve Hacettepe Ruhsal Uyum Envanteri puanları KWH testi sonuçları

\begin{tabular}{llccccc}
\hline & Baba Yaşı & $\mathrm{n}$ & $\overline{\mathrm{x}}$ & $\mathrm{S}$ & $\mathrm{H}$ & $\mathrm{p}$ \\
\hline Çocuk Ego & 26-30 yaş & 41 & 68,53 & 12,13 & 9,257 & 0,055 \\
Sağlamlığı Ölçeği & 31-35 yaş & 126 & 65,11 & 12,57 & & \\
& 36-40 yaş & 100 & 63,20 & 12,22 & & \\
& 41-45 yaş & 28 & 64,21 & 10,82 & & \\
& 46 yaş ve üzeri & 16 & 80,00 & 11,93 & & \\
\hline Hacettepe Ruhsal & 26-30 yaş & 41 & 9,87 & 6,69 & 0,084 & 0,999 \\
Uyum Envanteri & 31-35 yaş & 126 & 9,61 & 5,09 & & \\
& 36-40 yaş & 100 & 9,51 & 4,87 & & \\
& 41-45 yaş & 28 & 10,07 & 6,18 & & \\
& 46 yaş ve üzeri & 16 & 9,87 & 5,63 & & \\
\hline
\end{tabular}

Tablo 6'ya göre çocukların baba yaşı ile Çocuk Ego Sağlamlığı Ölçeği ve Hacettepe Ruhsal Uyum Envanteri ortalama puanları arasındaki fark anlamlı değildir $(p<0,05)$. Bu bulguya göre baba yaşı okul öncesi çocuklarının ego sağlamlık durumları ve ruhsal uyumlarında anlamlı farklılık oluşturmamaktadır.

Tablo 7. Anne öğrenim durumuna göre Çocuk Ego Sağlamlığı Ölçeği ve Hacettepe Ruhsal Uyum Envanteri puanları KWH testi sonuçları

\begin{tabular}{llccccc}
\hline & Anne Öğrenim & $\mathrm{n}$ & $\overline{\mathrm{x}}$ & $\mathrm{S}$ & $\mathrm{H}$ & $\mathrm{p}$ \\
& Durumu & & & & & \\
\hline Çocuk Ego Sağlamlığı & İlkokul & 17 & 70,11 & 12,45 & 5,174 & 0,395 \\
Ölçeği & Ortaokul & 16 & 59,75 & 17,66 & & \\
& Lise & 63 & 65,73 & 10,99 & & \\
& Ön Lisans & 49 & 66,48 & 14,09 & & \\
& Lisans & 137 & 65,09 & 11,58 & & \\
& Lisans üstü & 29 & 67,27 & 10,23 & & \\
\hline Hacettepe Ruhsal & İlkokul & 17 & 10,17 & 7,46 & 12,402 & $\mathbf{0 , 0 3 0 *}$ \\
Uyum Envanteri & Ortaokul & 16 & 11,68 & 7,16 & & \\
& Lise & 63 & 11,20 & 5,26 & Fark: Lise-Lisans \\
& Ön Lisans & 49 & 10,22 & 5,65 & & \\
& Lisans & 137 & 8,61 & 4,81 & & \\
& Lisans üstü & 29 & 9,03 & 3,99 & & \\
\end{tabular}

${ }^{*} \mathrm{p}<0,05$

Tablo 7 incelendiğinde, anne öğrenim durumu ile Çocuk Ego Sağlamlığı Ölçeği ve ortalama puanlarının farklılaşmadığı görülmektedir $(p>0,05)$. Anne öğrenim durumu ile çocuklarının Hacettepe Ruhsal Uyum Envanteri ortalama puanları arasındaki fark anlamlıdır $(p=0,030)$ Annesi lise mezunu olan çocukların Hacettepe Ruhsal Uyum Envanteri ortalama puanları $(\overline{\mathrm{x}}=11,20)$ annesi lisans mezunu olanların puanından $(\overline{\mathrm{x}}=8,61)$ anlamlı düzeyde daha yüksektir. Bu bulguya göre anne öğrenim durumu okul öncesi çocuklarının ego sağlamlığında 
anlamlı farklılık oluşturmazken annesi lise mezunu olan çocukların ruhsal uyumları annesi lisans mezunu olan çocuklara göre daha yüksek düzeydedir.

Tablo 8. Baba öğrenim durumuna göre Çocuk Ego Sağlamlığı Ölçeği ve Hacettepe Ruhsal Uyum Envanteri puanları KWH testi sonuçları

\begin{tabular}{llccccc}
\hline & Baba Öğrenim & $\mathrm{n}$ & $\overline{\mathrm{x}}$ & $\mathrm{S}$ & $\mathrm{H}$ & $\mathrm{p}$ \\
& Durumu & & & & & \\
\hline Çocuk Ego & İlkokul & 17 & 66,70 & 10,09 & 2,959 & 0,706 \\
Sağlamlığı Ölçeği & Ortaokul & 22 & 63,18 & 13,10 & & \\
& Lise & 75 & 66,36 & 13,56 & & \\
& Ön Lisans & 29 & 62,00 & 12,39 & & \\
& Lisans & 125 & 65,06 & 11,49 & & \\
& Lisans üstü & 43 & 64,83 & 12,61 & & \\
\hline Hacettepe Ruhsal & İlkokul & 17 & 11,00 & 5,97 & 12,327 & $\mathbf{0 , 0 3 1 *}$ \\
Uyum Envanteri & Ortaokul & 22 & 13,28 & 5,83 & Fark: Orta-Lise, Ön \\
& Lise & 75 & 9,04 & 5,98 & lisanss, lisans \\
& Ön Lisans & 29 & 10,03 & 5,60 & & \\
& Lisans & 125 & 9,11 & 4,90 & & \\
& Lisans üstü & 43 & 9,90 & 4,88 & & \\
& & & & & & \\
\end{tabular}

$* \mathrm{p}<0,05$

Tablo 8 incelendiğinde, babaların öğrenim durumuna göre çocukların Çocuk Ego Sağlamlığı Ölçeği ortalama puanlarının farklılaşmadığı görülmektedir $(p>0,05)$. Baba öğrenim durumu ile çocukların Hacettepe Ruhsal Uyum Envanteri ortalama puanları arasındaki fark anlamlıdır $(p=0,031)$. Babası ortaokul mezunu olan çocukların Hacettepe Ruhsal Uyum Envanteri ortalama puanları $(\overline{\mathrm{x}}=13,28)$ babası lise, ön lisans ve lisans mezunu olanların puanından $(\overline{\mathrm{x}}=9,04 ; \overline{\mathrm{x}}=10,03 ; \overline{\mathrm{x}}=9,90)$ anlamlı düzeyde daha yüksektir. Bu bulguya göre baba öğrenim durumu okul öncesi çocukların ego sağlamlığında anlamlı fark oluşturmazken babası ortaokul mezunu olan çocukların ruhsal uyumları babası lise, ön lisans ve lisans mezunu olanlardan daha yüksektir.

Çocuk Ego Sağlamlığı Ölçeği ve Hacettepe Ruhsal Uyum Envanteri ortalama puanları Spearman Brown Korelasyon analizi sonuçları Tablo 9'da verilmiştir.

Tablo 9. Çocukların Çocuk Ego Sağlamlığı Ölçeği ve Hacettepe Ruhsal Uyum Envanteri puanları korelasyon analizi sonuçları

\begin{tabular}{lccc}
\hline & & $\begin{array}{c}\text { Çocuk Ego Sağlamlığ } \\
\text { Ölçeği }\end{array}$ & $\begin{array}{c}\text { Hacettepe Ruhsal } \\
\text { Uyum Envanteri }\end{array}$ \\
\hline Çocuk Ego Sağlamlığı Ölçeği & $\mathrm{r}$ & 1,000 & \\
& $\mathrm{p}$ & $\cdot$ & 1,000 \\
Hacettepe Ruhsal Uyum Envanteri & $\mathrm{r}$ & $-0,003$ &. \\
\hline
\end{tabular}


Tablo 9'a göre okul öncesi çocukların Ego Sağlamlığı Ölçeği ile Hacettepe Ruhsal Uyum Envanteri ortalama puanları arasında istatistiksel olarak anlamlı bir ilişki yoktur $(\mathrm{p}>0,05)$.

\section{TARTIŞMA ve SONUÇ}

Çalışmada, okul öncesi dönem çocuklarının ego sağlamlığı ile ruhsal uyumları arasındaki ilişki, ayrıca bazı demografik değişkenlere göre ego sağlamlık ve ruhsal uyum durumları incelenmiştir. Bu bölümde, çalışmanın alt problemlerine göre elde edilen sonuçlar verilerek tartış1lmıştır.

Çalışmada, okul öncesi çocukların ego sağlamlığının cinsiyete göre anlamlı bir farklılık göstermediği belirlenmiştir. Ego sağlamlığg konusunda yapılan araştırmalara bakıldığında çocukların cinsiyeti ve yaşı ile ego sağlamlığı arasında anlamlı bir ilişki olmadığı saptanmıştır (Çiftçi Arıdağ ve Ünsal Seydooğulları, 2018; Erkoç, 2019; Önder vd., 2016. Taylor ve diğerleri (2013) yapmış oldukları çalışmada okul öncesi dönemde çocukların ego sağlamlık düzeylerinin cinsiyete göre farklılaşmadığını belirtmişlerdir. Tanyeri (2016) yetişkinlerle ve Topbay (2016) ortaokul öğrencileriyle yapmış oldukları çalışmalarda ego sağlamlığında cinsiyete bağlı anlamlı bir fark bulamamışlardır. Bu bulgular, çalışmanın cinsiyete ilişkin ego sağlamlığı bulgularıyla paralellik göstermektedir. Farklı bir bulgu olarak Bayındır (2018) tarafından okul öncesi çocuklarla yapılan bir çalışmada, kızların erkeklere göre ego sağlamlığı düzeyi anlamlı derecede yüksek bulunmuştur. Buna göre ego sağlamlığ konusunun çocukların cinsiyeti açısından farklı çalışmalarla incelenmeye açık olduğu, aynı zamanda ego sağlamlığının yalnızca cinsiyetin değil bazı değişkenlerin ortak etkisiyle farklılık gösterdiği de söylenebilir.

Çalışmada, okul öncesi çocukların ego sağlamlığı ve ruhsal uyumlarının kardeş sayısına göre anlamlı bir farklılık göstermediği belirlenmiştir. Traş, Öztemel ve Kağnıcı (2018), Esen-Aktay (2010) ve Atik (2013) tarafından lise ve üzeri yaş grubundaki bireylerle yapılan çalışmalarda kardeş sayılarının ego sağlamlığı düzeylerinde anlamlı bir farklılık olmadığı ortaya konmuştur. Ayrıca konuyla ilgili atıfta bulunulan çalışmalar, büyük yaş gruplarıyla yapılmıştır. Okul öncesi yaş grubunda kardeş sayısına göre ego sağlamlığının farklılaşması beklenen bir sonuç olarak düşünülebilir. Çünkü kardeşler arası ilişkiler dönemsel olarak farklılaşabilmektedir. Anne-baba öğrenim düzeyinin düşük ya da yüksek olması, çocuğun doğum sırası, yaşı, kardeş sayısı ve cinsiyeti, ailenin sosyoekonomik ve sosyokültürel durumu, çocuk yetiştirme tutum ve davranışlarını etkileyebilmektedir (Çubukçu, 2019; Özyürek, 2021). Çalışmada kardeş sayısının ego sağlamlığı ve ruhsal uyum üzerinde anlamlı bir farklılık oluşturmamasının nedeni, kardeşler arası yaş veya cinsiyet farkının olup olmamasından kaynaklanıyor olabilir. Bu çalışmada, kardeşlerin yaşı ve cinsiyetine ilişkin bilgiye ulaşılmamıştır. Bu durum çalışmanın sınırlılığı olarak kabul edilebilir.

Çalışmada anne-baba yaşına ve öğrenim durumuna göre ego sağlamlığı düzeyi arasında anlamlı bir fark ortaya çıkmamıştır. 2018'de Balaban Dağal ve Bayındır'ın yapmış oldukları çalışmada ego sağlamlık düzeyiyle anne-baba yaşı ve öğrenim durumu arasında 
anlamlı bir fark olmadığını belirtmişlerdir. Bu bulgunun çalışma bulgularını desteklediği söylenebilir. Öğrenim durumu açısından, yurt dişında yapılan bazı çalışmalarda anne-baba öğrenim düzeyinin ego sağlamlığında olumlu ya da olumsuz bir farklılık oluşturduğu belirtilmektedir (Sangma, 2014; Sue-Lynn ve Yoo'nun, 2015). Çalışmada, okul öncesi çocukların anne-baba yaşına göre ruhsal uyumlarının farklılık göstermediği belirlenmiştir. Anne ve baba öğrenimiyle çocukların ruhsal uyumları arasındaki ilişki manidar bulunmuş, annesi lise mezunu olan çocukların ruhsal uyumlarının annesi lisans mezunu olan çocuklardan ve babası ortaokul mezunu olan çocukların ruhsal uyumlarının babası lise, ön lisans ve lisans mezunu olanlardan daha yüksek olduğu belirlenmiştir. Ruhsal uyum konusunda Coşkun (1994) tarafından yapılan çalışmada, anne ve babaların öğrenim düzeyiyle çocukların ruhsal uyumları arasında anlamlı bir fark olmadığı belirtilmiştir. Bu bulgu, araştırma bulgularından farklıdır. Demografik değişkenlerden etkilenen olumlu ve olumsuz anne-baba tutumlarına bağlı olarak çocukların ruhsal uyumlarında farklılıklar gözlenebilir. Ruhsal uyum konusunda yapılan çalışmaların kısıtlı sayıda olduğu düşünüldüğünde bu konuda daha kapsamlı çalışmalar yapılması gerektiği söylenebilir.

Çalışma bulgularına göre okul öncesi çocukların ego sağlamlık düzeyleri ile ruhsal uyumları arasında anlamlı bir ilişki olmadığı belirlenmiştir. Ego sağlamlığı, ruhsal sağlıkla ilişkilidir ve ruhsal yönden sağlıklı bireylerin yaşama uyum yeteneği daha yüksektir (Masten ve Gewirtz, 2006; Ramirez, 2007). Benzer şekilde ego sağlamlığı da bireyin zorluklarla başa çıkma veya farklı durumlara uyumlarını ifade etmektedir (Masten ve Coatsworth, 1998). Bu bilgilere dayalı olarak çocukların ego sağlamlıklarıyla ruhsal uyumlarının ilişkili olması beklenen bir sonuçtur. Taylor ve arkadaşları (2013) yapmış oldukları çalışmada çocukluk döneminde ego sağlamlık seviyesini belirlemenin, yaşamın ileri döneminde ruhsal uyum ve psikolojik iyi olma durumlarını sağlayabileceğini ifade etmişlerdir. Çalışmada ego sağlamlığının ruhsal uyum üzerinde anlamlı bir etkisinin olmayışı, ruhsal uyum üzerinde farklı değişkenlerin ortak etkisinin olabileceğini düşündürmektedir. Ayrıca annelerin değerlendirmesine göre elde edilen verilerde, kullanılan her iki ölçekten elde edilen puanlar ortalama düzeyde olup alt-orta-üst puan ortalaması gibi belirgin bir farklılık oluşmadığı görülmüştür. Bu durum puanlar arası ilişkinin belirlenmesini güçleştirmiştir.

Sonuç olarak okul öncesi çocukların ego sağlamlık düzeyleri ile ruhsal uyumları arasında anlamlı bir ilişki olmadığı; çocukların cinsiyetine, kardeş sayısına, anne-baba yaşına göre ego sağlamlıkları ve ruhsal uyumlarının farklılık göstermediği belirlenmiştir. Anne ve babaların öğrenim durumuna göre, çocukların ego sağlamlıkları farklılık göstermemiş, fakat ruhsal uyumları farklılık göstermiş; annesi lise mezunu olan çocukların ruhsal uyumlarının annesi lisans mezunu olan çocuklara göre daha yüksek ve babası ortaokul mezunu olan çocukların ruhsal uyumları babası lise, ön lisans ve lisans mezunu olanlardan daha yüksek olarak belirlenmiştir. Çocukluğun erken yıllarından itibaren gelişimin temelleri oluşmaktadır. Okul öncesi yıllarda çocukların sağlıklı gelişiminin yaşam boyu etkileri dikkate alındığında, erken yaşlardan itibaren çocukların karşılaştıkları problemlerle mücadele etmeleri veya yeni karşılaştıkları duruma uyum sağlayabilmeleri için desteklenmeye ihtiyaçları vardır. 
Küçük yaşlardan itibaren ego sağlamlığının geliştirilmesinde, anne-baba ve eğitimcilerin çocuklara yapabilecekleri düzeyde sorumluluklar vermeleri, karşılaştıkları problemleri çözmeleri için fursat tanımaları, kendilerini ifade edebilecekleri ortamlar sunmaları gerekmektedir. Çocukların ego sağlamlığı ve ruhsal uyumunu artırmak için yaşama bakış açısını geliştirmeye yönelik olarak yetişkin desteğine gereksinimi vardır. Yetişkinlerin problem çözme, yaşamda karşılaşılan olumsuzluklar karşısında ümitvar olmak, olumsuzluklar yerine olumlu durumlara odaklanmak konusunda rol model olması ve problem çözme becerilerini geliştirici stratejileri kullanmayı öğretmesi önerilebilir. Çocuğun güçlü yönleri fark edilerek iletişim ve duygu düzenleme becerilerinin geliştirilmesi konusunda desteklenebilir. Benzer bir çalışmada daha geniş bir örneklem grubunda ölçeklerden elde edilen puanların alt, orta ve üst düzey olarak ele alınarak karşılaştırmalı şekilde yapılması önerilebilir. Çocuklarda ego sağlamlığı ve ruhsal uyuma yönelik çalışmaların kısıtlı olduğu görülmektedir. Farklı değişkenler ele alınarak çocuklarda ego sağlamlığı ve ruhsal uyum konuları üzerinde çalışılabilir. Çocuk ve ailelere yönelik deneysel veya yarı deneysel eğitim programları düzenlenerek bu programların etkisi, ego sağlamlığı veya ruhsal uyumu etkileyen olumlu ve olumsuz faktörlerin neler olduğu incelenebilir.

\section{KAYNAKLAR}

Alisinanoğlu F, Ulutaş İ. (2000). Çocuklarda kaygı ve bunu etkileyen etmenler. Milli Ĕ̈itim Dergisi. 145, 15-19.

Atik, E. L. (2013). Liseli ergenlerde bağlanma stilleri ve psikolojik săglamlık düzeyleri arasındaki ilişkide öz-yansıtma ve içgörünün rolü. (Yayınlanmamış yüksek lisans tezi). İstanbul Bilim Üniversitesi Sosyal Bilimler Enstitüsü, İstanbul.

Avc1, N. (2007). Gelişimde 0-3 yaş yaşama merhaba (4. Baskı). İstanbul: Morpa.

Balaban Dağal, A. ve Bayındır, D. (2018). Okul öncesi dönem çocuklarının ego sağlamlık düzeylerinin incelenmesi. Erken Çocukluk Çalışmaları Dergisi, 2(1), 132-150.

Bayındır, D., Önder, A. ve Balaban Dağal, A. (2016). Temperament and resiliency as predictor factors of preschoolers' school readiness. 10. Sosyal ve Davranış Bilimleri Araştırma Konferansında sunulan bildiri, Saraybosna Üniversitesi, Saraybosna.

Berk, L.E. (2013). Bebekler ve çocuklar (Çev.Ed.: N. Iş1koğlu Erdoğan). Ankara: Nobel.

Block J. H. \& Block J. (1980). The role of ego-control and ego-resiliency in the organization of behavior. In W. A. Collins (Ed.). Minnesota Symposia on Child Psychology, 13, 39101. NJ: Erlbaum; Hillsdale.

Block, J. ve Block, J. H. (2006). Venturing a 30-year longitudinal study. American Psychologist, 61, 315-327. Doi:10.1037/0003-066X.61.4.315.

Brooks, J. E. (2006). Strengthening resilience in children and youths: Maximizing opportunities in the schools. Children \& Schools, 28(2), 69-76.

Çelik, E. (2013). Lise son sınıf öğrencilerinin yılmazlık özelliklerinin duygusal dışavurum açısından incelenmesi. Atatürk Üniversitesi Sosyal Bilimler Enstitüsü Dergisi, 17 (2), 221-236.

Çiftçi Arıdağ, N. ve Ünsal Seydooğulları, S. (2018). Lise öğrencilerinin yaşam doyumu ve yılmazlık düzeylerinin anne-baba tutumlarıyla ilişkisi açısından incelenmesi. 
Hacettepe Üniversitesi Eğitim Fakültesi Dergisi, 34(4), 1037-1060. doi: 10.16986/HUJE.2018038527.

Eisenberg, N., Spinrad, T. L. ve Morris, A. S. (2002). Regulation, resiliency and quality of social functioning. Self and Identity, 1, 121-128.

Eren, E. (2001). Örgütsel davranış ve yönetim psikolojisi. (7. Basım). İstanbul: Beta.

Erkoç, N. (2019). Illkokul yöneticilerinin yllmazlık, duygusal zeka ve yönetsel etkililik düzeyleri arasındaki ilişkinin incelenmesi. (Yayınlanmamış yüksek lisans tezi). İnönü Üniversitesi, Malatya.

Esen-Aktay, T. (2010). Risk altındaki ortä̈ğretim 9. ve 10. sinıf ögrrencilerinin kendini toparlama güçlerinin incelenmesi. (Yayınlanmamış yüksek lisans tezi). Gazi Üniversitesi, Ankara.

Gençtan, E. (1993). Çă̆daş yaşam ve normal dışı davranışlar. (7. Bask1). İstanbul: Remzi.

Gizir, C. A. (2004). Academic Resilience: An Investigation of protective factors contributing to the academic achievement of eighth grade students in poverty (Unpublished Master's thesis). https://tez.yok.gov.tr/UlusalTezMerkezi/tezSorguSonucYeni.jsp

Gizir, C. A. (2007). Psikolojik sağlamlık, risk faktörleri ve koruyucu faktörler üzerinde bir derleme çalışması. Türk Psikolojik Danışma ve Rehberlik Dergisi, 3, 28, 113-128.

Gökler, B. ve Öktem F. (1985). Bir gecekondu ilkokulu öğrencilerinde ruhsal uyum taramas1. Toplum ve Hekim, 36, 24-27.

Hofer, C., Eisenberg, N. ve Reiser, M. (2010). The role of socialization, effortful control, and ego-resiliency in french adolescents' social functioning. Journal of Research on Adolescence, 20, 555-582. Doi: 10.1111/J.1532-7795.2010.00650.X

Karasar, N. (2014). Bilimsel Araştırma yöntemi-kavramlar-ilkeler-teknikler. Ankara: Nobel.

Kurç, G. (1990). Kişisel, sosyo-ekonomik ve kültürel bazı değişkenlerin gençlerin uyum alanları ve uyum yöntemlerine etkisi. Eğitim ve Bilim, 14(76), 3-9.

Kuş, E. (2009). Nicel-nitel araştırma teknikleri: sosyal bilimlerde araştırma teknikleri nicel mi? nitel mi? (3. Baskı). Ankara: Anı.

Kwok, O., Hughes, J. N. ve Luo, W. (2007). Role of resilient personality on lower achieving first grade students' current and future achievement. Journal of School Psychology, 45, 61-82.

Luthar, S. S., Cicchetti, D. ve Becker, B. (2000). The construct of resilience: a critical evaluation and guidelines for future work. Child Development, 71(3), 543-562.

Martel, M. M., Nigg, J. T., Wong, M. M., Fitzgerald, H. E., Jester, J. M. ve Puttler, L. I. (2007). Childhood and adolescent resiliency, regulation, and executive functioning in relation to adolescent problems and competence in a high-risk sample. Development and Psychopathology, 19, 541-563. Doi: 10.1017/S0954579407070265

Masten, A. S. ve Gewirtz, A. H. (2006). Resilience in development: The importance of early childhood. Centre of Excellence for Early Childhood Development. Retrieved from the University of Minnesota Digital Conservancy.

Masten, A. S. (2011). Resilience in children threatened by extreme adversity: frameworkfor research, practice, and translational synergy. Development and Psychopathology, 23, 493-506. Doi: 10.1017/S0954579411000198 
Masten, A. ve Coatsworth, J. D. (1998). The development of competence in favorable and unfavorable environments: lessons from research on successful children. American Psychologist, 53(2), 205-220.

Oktuğ, Z. (2007). Freud'un kişilik birimleri (id-ego-süperego) ile reklam iletisinin izleyici üstünde yarattı̆̆ etkiler arasındaki bağıntı: Magnum, Kalbim Benecol ve Lösev reklamları üzerine bir araştırma. (Yayınlanmamış yüksek lisans tezi). İstanbul Kültür Üniversitesi, İstanbul.

Önder, A. ve Gülay-Ogelman, H. (2011). The reliability-validity study for the ego resiliency scale (teacher-mother-father forms) for children aged between 5 and 6 . Uluslararasi Hakemli Akademik Sosyal Bilimler Dergisi, 2(1), 5-21.

Önder, A., Balaban Dağal, A. ve Bayındır, D. (2016). The Effect of emotion regulation skills on ego resilience in preschoolers. 8th International Conference on Learning, Education and Pedagogy (LEAP), Dubai. Erişim Adresi: https://Adtelweb.Org/Proceeedings/17.Pdf.

Öngören, S. ve Y1lmaz, E. (2018). Rastlantısal krizler. K. Tepeli ve E. Durualp (Ed.). Aile yaşam döngüsü (s. 287-328). Ankara: Hedef.

Özyürek, A. (2021). Aile ve ebeveynlik. A. Özyürek ve A. Çetin (Ed). Farklı kültürlerde aile ve çocuk içinde (s.1-30). Ankara: Vize.

Prince-Embury, S. (2015). Assessing personal resiliency in school settings: the resiliency scales for children and adolescents. Journal Of Psychologists and Counsellors in Schools, 25 (1). 55-65.

Ramirez, E.R. (2007). Resilience: A Concept Analysis. Nursing Forum, 42, 73-82.

Sangma, K. (2014). The effects of ego-resilience on the trajectories of school adaptation among adolescents in poverty. (Yayınlanmamış yüksek lisans tezi). Dharward Üniversitesi.

Sue- Lynn, K. ve Yoo, J.P. (2015). The effects of ego-resilience on the trajectories of school adaptation among adolescents in poverty. Bangkok Uluslararasi Sosyal Bilimler Konferansinda sunulan bildiri, Bangkok, Tayland.

Stams, G.-J. J. M., Juffer, F., Van Ijzendoorn, M. H. ve Hocksbergen, R. C. (2001). Attachment-based intervention in adoptive families in infancy and children's development at age 7: two follow-up studies. British Journal of Developmental Psychology, 19, 159-180. Doi: 10.1348/ 026151001166010.

Stipek, D., Recchia, S. ve Mcclintic, S. (1992). Self-evaluation in young children. Monographs of the Society for Research in Child Development, 57, 1-126.

Tanyeri, E. (2016). 23 yaş ve üzeri heteroseksüel ve homoseksüel bireylerin erken dönem uyumsuz şemalarının ilişkilerde yükleme tarzları ve psikolojik sağlamlı üzerine etkisi. (Yayınlanmamış yüksek lisans tezi). Beykent Üniversitesi Sosyal Bilimler Enstitüsü, İstanbul.

Taylor, Z.E., Eisenberg, N., Spinrad, T.L. ve Widaman, K.F. (2013). Longitudinal relations of intrusive parenting and effortful control to ego-resiliency during early childhood, Child Development, 84 (4), 1145-1151.

Topbay, Y. (2016). Ortaokul öğrencilerinin psikolojik sağlamlık düzeylerinin algllanan sosyal destek ve aile işlevleri açısından incelenmesi. (Yayınlanmamış yüksek lisans tezi). Beykent Üniversitesi Sosyal Bilimler Enstitüsü, İstanbul. 
Traş, Z., Öztemel, K. ve Kağnıcı, E. (2019) Öğretmen adaylarında kendini toparlama gücünün çeşitli değişkenlere göre incelenmesi. Necmettin Erbakan Üniversitesi Ereğli Eğitim Fakültesi Dergisi, 1(1), 29-41.

Wolkow, K. E. ve Ferguson, H. B. (2001). Community factors in the development of resiliency: considerations and future directions. Communitymental Health Journal, 37(6), 489-498.

Yanbastı, G. (1990). Kişilik kuramları. İzmir: Ege Üniversitesi.

Yavuzer, H. (1982) Çocuk psikolojisi i, duygusal ve toplumsal gelişim. İstanbul: İstanbul Üniversitesi Edebiyat Fakültesi.

Yörükoğlu A. (1996). Gençlik çă̆l: ruh sağlı̆̆ı ve ruhsal sorunları. (9. Basım). İstanbul: Özgür.

Atıf İçin/For Citation: Çetinkaya, A. ve Özyürek, A. (2021). Okul öncesi dönem çocuklarda ego sağlamlığı ve ruhsal uyum arasındaki ilişkinin incelenmesi. Uluslararası Eğitim Bilim ve Teknoloji Dergisi, 7(3), 147-163. 